\title{
XOR - Possible Correlations with Oxidative Stress and Inflammation Markers in the Context of Diabetic Kidney Disease
}

\author{
ALEXANDRA TOTAN ${ }^{1}$, ANDRA-ELENA BALCANGIU-STROESCU ${ }^{2, *}$, MARINA MELESCANU IMRE ${ }^{5 *}$, DANIELA MIRICESCU ${ }^{1}$, \\ DANIELA BALAN ${ }^{2}$, IULIA-IOANA STANESCU², DORIN IONESCU ${ }^{3,4}$, DELIA TIMOFTE ${ }^{5}$, MARIA DANIELA TANASESCU ${ }^{3}$, \\ MARIA GREABU ${ }^{1}$ \\ 'University of Medicine and Pharmacy Carol Davila, Faculty of Dental Medicine, Department of Biochemistry, 8 Eroii Sanitari \\ Blvd, 050474, Bucharest, Romania \\ 2University of Medicine and Pharmacy Carol Davila, Faculty of Dental Medicine, Department of Physiology, 8 Eroii Sanitari Blvd, \\ 050474, Bucharest, Romania \\ 3University of Medicine and Pharmacy Carol Davila, Faculty of Medicine, Department of Medical Semiology, Discipline of \\ Internal Medicine I and Nephrology Biochemistry, 8 Eroii Sanitari Blvd, 050474, Bucharest, Romania \\ 4Emergency University Hospital, 169 Splaiul Independentei, 050098, Bucharest, Romania \\ 5Emergency University Hospital, Department of Dialysis, 169 Splaiul Independentei, 050098, Bucharest, Romania
}

\begin{abstract}
Xanthine oxidoreductase (XOR) activity plays an important role as a pivotal source of reactive oxygen species. The aim of our study was to investigate possible correlations of XOR serum levels with oxidative stress (total antioxidant capacity - TAC, anti-oxidative stress responsive 1 antibody - OXSR1) and inflammation markers (interleukin 6- IL-6), in 20 hemodialysis diabetic patients. The present study included the hemodialysis diabetic patients group (10 males and 10 females) and the control group (20 healthy volunteers). For serum XOR ( $\mathrm{ng} / \mathrm{mL}), T A C(\mathrm{U} / \mathrm{mL})$ and OXSR1 $(\mathrm{ng} / \mathrm{ml})$ measurements we have used the ELISA technique. Serum IL 6 ( $\mathrm{pg} / \mathrm{mL}$ ) was performed using an automatic immunoassay system (Immulite 1000, Siemens- Germany). Comparing the two groups, our results revealed significantly increased serum

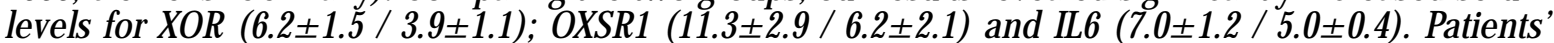
serum levels of TAC were significantly decreased compared with the control group values (25.2 \pm 3.9 / 33.5 \pm 2.8 ). It becomes more and more obvious that oxidative stress is an important element initiating diabetic microvascular complications, including diabetic kidney disease. Our results suggested that XOR should be regarded as an important target in the attempt to reduce oxidative stress in the context of diabetic kidney disease.
\end{abstract}

Keywords: xanthine oxidoreductase, oxidative stress, inflammation, diabetic kidney disease

Diabetes is more and more incriminated as the main cause of chronic renal failure [1]. Diabetic kidney disease (DKD), also known as diabetic nephropathy (DN), is clinically characterized by a progressive decline in the glomerular filtration rate, illustrated by a gradual increase of albuminuria [1].

Chronic hyperglycemia, the characteristic of diabetes, represents a main cause of several pathological molecular processes activation, which will seriously affect the glomerular endothelial cells, smooth muscle cells, mesangial cells, podocytes, and cells of the tubular and collecting ducts [2].

Xanthine oxidoreductase (XOR) is responsible for the formation of uric acid from hypoxanthine and xanthine, leading to superoxide and other reactive oxygen species (ROS) production [3]. Consequently, XOR activation contributes as a principal actor to the development and progresion of oxidative stress (OS)-related tissue injury [4].

In the literature there are reported studies associating plasma XOR activity with obesity, smoking, liver dysfunction, hyperuricemia, dyslipidemia and insulin resistance [5-7].

The aim of our study was to investigate possible relationships between XOR serum activity and OS (illustrated by serum total antioxidant capacity - TAC and anti-oxidative stress responsive 1 antibody - OXSR1) and inflammation markers (interleukin 6-IL-6), in 20 hemodialysis diabetic patients.

\section{Experimental part}

The present study included the hemodialysis diabetic patients group ( 10 males and 10 females; aged 41 - 65) GD and the control group ( 20 healthy volunteers; aged 35 62) - GC. All the participants, patients and controls, provided the informed consent to participate in the study.

\section{Measurement of serum XOR activity}

Measurement of plasma XOR activity was performed using freshly frozen samples that were maintained at -80 ${ }^{\circ} \mathrm{C}$ until the time of assay. Plasma XOR activity was measured using ELISA technique and an assay kit from Wuhan Fine biotech, China.

\section{Measurement of serum OS markers}

Measurement of serum OS markers was performed using freshly frozen samples that were maintained at $80{ }^{\circ} \mathrm{C}$ until the time of assay. Serum OXSR1 levels were measured using ELISA technique and an assay kit from Abbexa, UK. Plasma OXSR1 levels were measured using ELISA technique and an assay kit from Blue Gene, India.

\section{Measurement of serum IL-6}

Measurement of serum IL- 6 levels was performed using freshly frozen samples that were maintained at $-80^{\circ} \mathrm{C}$ until the time of assay. Serum IL-6 $(\mathrm{pg} / \mathrm{mL}$ ) was performed using an automatic immunoassay system (Immulite 1000, Siemens- Germany). 


\begin{tabular}{|c|c|c|c|}
\hline Parameter & GD & GC & p \\
\hline XOR $(\mathrm{ng} / \mathrm{ml})$ & $6.2 \pm 1.5$ & $3.9 \pm 1.1$ & $<0.01$ \\
\hline TAC (U/ml) & $25.2 \pm 3.9$ & $33.5 \pm 2.8$ & $<0.01$ \\
\hline OXSR1(ng/ml) & $11.3 \pm 2.9$ & $6.2 \pm 2.1$ & $<0.01$ \\
\hline IL-6 $(\mathrm{pg} / \mathrm{ml})$ & $7.0 \pm 1.2$ & $5.0 \pm 0.4$ & $<0.01$ \\
\hline
\end{tabular}

Table 1

EXPERIMENTAL DATA OBTAINED IN THE TWO STUDIED GROUPS, GD AND GC

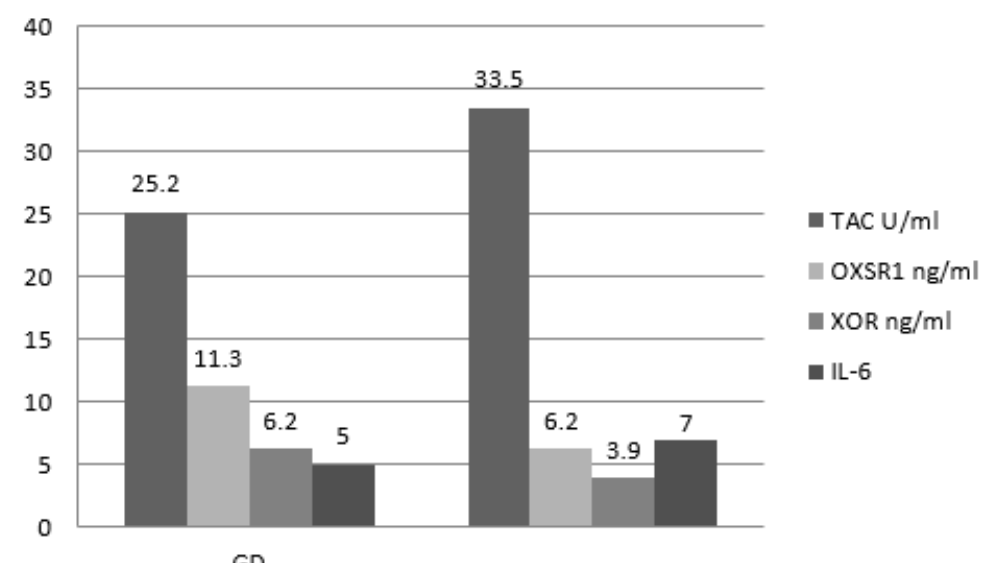

Fig. 1. Experimental data obtained in the two studied groups, GD and GC

\section{Statistical analysis}

Comparison between the two studied groups was done with Student's t test for parametric parameters.

\section{Results and discussions}

Our experimental data are summerized in table 1.

Our results revealed significantly increased serum levels for XOR $(6.2 \pm 1.5 \mathrm{ng} / \mathrm{mL})$ in GD compared with $\mathrm{GC}$ $(3.9 \pm 1.1 \mathrm{ng} / \mathrm{mL})(p<0.01)$ (fig. 1$)$.

In terms of OS parameters, our experimental data illustrated:

- significant increase for serum OXSR1 levels in GD $(11.3 \pm 2.9 \mathrm{ng} / \mathrm{mL})$ compared with $\mathrm{GC}(6.2 \pm 2.1 \mathrm{ng} / \mathrm{mL})$ $(p<0.01)$ (fig. 1).

- significant decrease for serum TAC levels in GD $(25.2 \pm 3.9 \mathrm{U} / \mathrm{mL})$ compared with $\mathrm{GC}(33.5 \pm 2.8 \mathrm{U} / \mathrm{mL})$ $(p<0.01)$ (fig. 1).

The IL-6 serum levels have marked a significant increase $(p<0.01)$ in $\mathrm{GD}(7.0 \pm 1.2 \mathrm{pg} / \mathrm{mL})$ versus GC $(5.0 \pm 0.4 \mathrm{pg} /$ $\mathrm{mL}$ ) (fig. 1).

Hyperglycemia-induced ROS over production triggers the recruitment of numerous inflammatory cells and, consequently, production of transcription factors, inflammatory cytokines and growth factors, all deeply involved in the molecular pathological mechanism of DKD [8]. Excessive renal infiltration of macrophages and T cells represents a key step in renal damage initiation [8].

More and more experimental evidence reveal ROS overproduction and OS as main players in connecting the kidney altered metabolic pathways with disrupted renal hemodynamics, leading consequentley to DKD $[9,10,19]$. These altered metabolic pathways ultimately will lead to inflammation, endothelial dysfunction and fibrosis $[9,10]$. Renal OS is often regarded as the consequence of the upregulation of pro-oxidant enzyme-induced ROS overproduction and concomitant antioxidants depletion $[9,10]$. [11]:

Mammals' XOR presents two interconvertible forms - xanthine dehydrogenase (XDH) - prefers NAD+ as an electron acceptor [12]

- xanthine oxidase (XO) - transfers the electrons directly to molecular oxygen, resulting in the production of ROS, superoxide anion and hydrogen peroxide, considered to be involved in the hypertension, dyslipidemia, and diabetes molecular mechanisms [12].

In the present study, we have revealed in GD a significantly increased activity of serum XOR activity, in the context of an intense serum OS (illustrated by high levels of OXSR1 and decreased TAC) and an inflammatory status (illustrated by incresed levels of IL-6).

Our results are concordant with those of the previous studies. Increased plasma XOR activity has also been reported in type 2 diabetes patients by Cosic V. et al [13]. XOR activity has been previously reported to be significantly and positively correlated with $\mathrm{HbAlc}$ in Asian type 2 diabetes patients [14]. In diabetic patients, redundant fructose may be involved in XOR activity increament probably by increasing ATP degradation to AMP, a uric acid precursor [15].

$X O R$ is strongly related to increased OS in the context of CKD $[16,17]$. Xantine oxidase $(X 0)$ represents the oxidative radical-forming isoform of XOR $[16,17]$. XO is formed by reversible or irreversible oxidation of the other XOR isoform, xanthine dehydrogenase $(X D H)$. It has recently been reported that $X O R$ redox, defined as the ratio of XO to total $X O R(X O$ and $X D H)$, changes the redox status in context of kidney dysfunction [18]. This is sustained by experimental data showing that allopurinol, the XOR inhibitor, reduced complications risk to approximately $30 \%$ in CKD patients $[16,17]$.

\section{Conclusions}

It becomes more and more obvious that oxidative stress is an important element initiating diabetic microvascular complications, including diabetic kidney disease. Our results suggested that XOR should be regarded as an important target in the attempt to reduce oxidative stress in the context of diabetic kidney disease.

How ever, additional studies are still needed in order to establish whether XOR and XO should be regarded as useful markers for predicting complications in CKD patients receiving hemodialysis. Moreover, further studies are needed in order to explore whether serum XOR activity can be reduced by strict uric acid and glycemic control in hemodialysis patients with type 2 diabetes. 


\section{References}

1. MOLITCH, M.E., DEFRONZO, R.A., FRANZ, M.J., KEANE, W.F., MOGENSEN,

C.E., PARVING, H.H., STEFFES, M.W., Diabetes Care, 27, no. 1, 2004, p. 79-83.

2. FORBES, J.M., COOPER, M.E., Physiol Rev, 93, no. 1, 2013, p. 137188.

3. AMAYA, Y., YAMAZAKI, K., SATO, M., NODA, K., NISHINO, T., NISHINO, T., J Biol Chem, 265, no. 24, 1990, p. 14170-14175.

4. KELLEY, E.E., Pharmacol Rep, 67, no. 4, 2015, p. 669-674.

5. WASHIO, K.W., KUSUNOKI, Y., MURASE, T., NAKAMURA, T., OSUGI, K., OHIGASHI, M., SUKENAGA, T., OCHI, F., MATSUO, T., KATSUNO, T., MORIWAKI, Y., YAMAMOTO, T., NAMBA, M., KOYAMA, H., Metabolism ,70, 2017, p. 51-56.

6. FURUHASHI, M., MATSUMOTO, M., TANAKA, M., MONIWA, N., MURASE, T., NAKAMURA, T., OHNISHI, H., SAITOH, S., SHIMAMOTO, K., MIURA, T., Circ J, 82, 2018, p. 1892-1899.

7. SUNAGAWA, S., SHIRAKURA, T., HOKAMA, N., KOZUKA, C., YONAMINE, M., NAMBA, T., MORISHIMA, S., NAKACHI, S., NISHI, Y., IKEMA, T., OKAMOTO, S., MATSUI, C., HASE, N., TAMURA, M., SHIMABUKURO, M., MASUZAKI, H., Diabetes Investig, 10, no. 1, 2018, p. 94-103.

8. FURUHASHI, M., MORI, K., TANAKA, M., MAEDA, T., MATSUMOTO, M., MURASE, T., NAKAMURA, T., KOYAMA, M., MONIWA, N., OHNISHI, H., SAITOH, S., SHIMAMOTO, K., MIURA, T., Endocr J., 65, no. 11, 2018, p. 1083-1092.
9. GILL, P.S., WILCOX, C.S., Antioxid Redox Signal, 8, 2006, p. 15971607.

10. KANETO, H., KATAKAMI, N., KAWAMORI, D., MIYATSUKA, T., SAKAMOTO, K., MATSUOKA, T.A., MATSUHISA, M., YAMASAKI, Y., Antioxid Redox Signal, 9, 2007, p. 355-366.

11. CORTE, E.D., STIRPE, F., Biochem J, 126, 1972, p. 739-745.

12. CANTU-MEDELLIN, N., KELLEY, E.E., Redox Biol, 1, 2013, p. 353358.

13. COSIC, V., ANTIC, S., PESIC, M., JOVANOVIC, O., KUNDALIC, S., DJ ORDJ EVIC, V.B., Clin Chem Lab Med, 39, 2001, p. 818-821.

14. KUPPUSAMY, U.R., INDRAN, M., ROKIAH, P., Diabet Med, 22, 2005, p. 1343-1346.

15. CHOI, H.K., WILLETT, W., CURHAN, G., JAMA, 304, no. 20, 2010, p. 2270-2278, (2010).

16. GOICOECHEA, M., DE VINUESA, S.G., VERDALLES, U., RUIZ-CARO, C., AMPUERO, J., RINCON, A., ARROYO, D., LUNO, J., Clinical J ournal of the American Society of Nephrology, 5, no. 8, 2010, p. 1388-1393. 17. TERAWAKI, H., NAKAYAMA, M., MIYAZAWA, E., MURATA, Y., NAKAYAMA, K., MATSUSHIMA, M., MIYAZAKI, M., SATO, H., SATO, M., SATO, T., TAGUMA, Y., ITO, S., Clinical and Experimental Nephrology, 17, no. 4, 2013, p. 549-553.

18. BOURDON, E., BLACHE, D., Antioxidants \& Redox Signaling, 3, no. 2, 2001, p. 293-311.

19. ALBULESCU, D.M., IONOVICl, N., MOLDOVAN, H.R., et. al., Romania Journal of Morphology andEmbriology, volume 58, issue: 2, pp. 545551, Published 2017

Manuscript received: 7.09 .2018 